\title{
Weed Control and Corn (Zea mays) Response to Planting Pattern and Herbicide Program with High Seeding Rates in North Carolina
}

\author{
Mitchell K. Williams, Ronnie W. Heiniger, Wesley J. Everman, and David L. Jordan \\ Department of Crop Science, North Carolina State University, P.O. Box 7620, Raleigh, NC 27695-7620, USA \\ Correspondence should be addressed to David L. Jordan; david_jordan@ncsu.edu
}

Received 10 March 2014; Revised 16 July 2014; Accepted 16 July 2014; Published 21 August 2014

Academic Editor: Tibor Janda

Copyright ( 2014 Mitchell K. Williams et al. This is an open access article distributed under the Creative Commons Attribution License, which permits unrestricted use, distribution, and reproduction in any medium, provided the original work is properly cited.

\begin{abstract}
Effective weed control in corn (Zea mays L.) is important to optimize yield. Concern over environmental impact of atrazine and selection for glyphosate resistance has increased the need to develop alternative strategies that use herbicides other than atrazine and glyphosate and appropriate cultural practices to control weeds. Research was conducted during 2011 and 2012 to determine weed and corn response to herbicide programs containing dicamba, glufosinate, and glyphosate applied postemergence alone or with atrazine in single- and twin-row planting patterns. Planting pattern had no effect on common ragweed (Ambrosia artemisiifolia L.) and Texas panicum (Panicum texanum L.) population and did not interact with herbicide program. Effective weed control hastened maturity in some but not all instances. Under weed-free conditions, corn grain yield was higher in 5 of 7 trials when planted in twin rows versus single rows at equivalent corn populations $\left(141,000\right.$ plants $\left.^{-1} \mathrm{a}^{-1}\right)$. These results suggest that while planting pattern may not impact weed control dramatically, planting corn in twin rows may be an effective alternative to single-row planting patterns because of increased yield under high corn populations.
\end{abstract}

\section{Introduction}

Effective weed management continues to be important in obtaining optimum corn yields [1]. Common ragweed is among the top ten most common weeds in corn in North Carolina [2]. Other troublesome broadleaf weeds include Palmer amaranth (Amaranthus palmeri S. Wats.), common lambsquarters (Chenopodium album L.), and sicklepod (Senna obtusifolia (L.) Irwin and Barneby) [2]. Texas panicum is considered one of the most troublesome weeds in corn production in the southeast US [3]. Several herbicides control Texas panicum in corn but not always completely [3-5].

Atrazine controls many broadleaf weeds and some grasses in corn and can be applied preplant incorporated (PPI), preemergence (PRE), or postemergence (POST) [6,7]. Although used on many hectares in the US [8], atrazine is no longer used in Europe because of concern of endocrine disruption in amphibians [9]. Residues of atrazine have been found in groundwater and surface water [10] and use of atrazine continues to be reviewed by the EPA in the US [7].
Development of herbicide-resistant biotypes has increased challenges in managing weeds in corn and other agronomic crops [11]. To decrease the likelihood of development of herbicide-resistant biotypes, rotation of herbicide modes of action is essential and should be coupled with cultural practices that minimize reproduction of herbicideresistant biotypes [11-14]. Although glyphosate can be very effective in glyphosate-tolerant corn to control common ragweed and Texas panicum, resistance of weeds to glyphosate has increased the need to use alternatives to glyphosate [14]. While biotypes of Texas panicum expressing resistance to glyphosate have not been reported, biotypes of common ragweed resistant to glyphosate have been documented in several geographic regions of the US [15]. Dicamba alone or in combination with other herbicides can be effective in controlling common ragweed and other broadleaf weeds $[16,17]$. Dicamba and glufosinate applied to small common ragweed can control this weed effectively and can serve as alternatives to atrazine and glyphosate in corn $[8,17-20]$. 
Higher plant populations and narrower row patterns enable corn to compete more effectively with weeds by expediting canopy closure and light interception [21-25]. However, excessive populations can negatively impact corn grain yield. Yield per plant decreased as plant population increased [21, 26]. Increasing plant populations in corn also decreased the number of leaves per plant and percent moisture in grain at harvest [27]. These changes reduced yield per plant because of less radiation interception per plant and consequently synthesized less assimilate for grain. High populations of corn also allow shading of the lower leaves of the corn plant, despite having a lower number of leaves per plant [28]. More frequent lodging was reported in corn planted in twin rows [29].

Research has shown varying results relative to weed suppression by higher corn populations or reduced row spacing of corn [25]. Increasing corn population from 33,000 to 133,000 plants ha $^{-1}$ reduced yellow nutsedge (Cyperus esculentus L.) growth [30]. Redroot pigweed (Amaranthus retroflexus L.) vegetative biomass was reduced by increased corn population [31]. However, response can be inconsistent due to hybrid selection, weed species, or environmental factors $[26,27,32]$.

Historically, equipment has limited transition to rows less than $76 \mathrm{~cm}$ for corn, but recent equipment modification has made planting in narrow rows feasible. One alternative to narrow row planting is planting corn in twin row patterns. Conventional corn grain combine headers are compatible with this planting pattern, allowing the use of existing equipment for production [33]. Yield response to planting in singlerow versus twin-row planting patterns has been variable in several crops. In soybean (Glycine max (L.) Merr.), twin rows planted $10-15 \mathrm{~cm}$ apart on $100 \mathrm{~cm}$ centers yielded more in twin rows compared to single rows [34]. Soybean yielded the same in the Mississippi Delta of the US when planted in twin-row and single-row patterns $[35,36]$. Gozubenli et al. [37] reported a $4 \%$ yield increase in twin-row corn at high populations $\left(60,000\right.$ plants ha $^{-1}$ to 135,000 plants $^{-1}$ ) compared with single-rows. Novacek et al. [38] reported no yield advantage of twin rows over single rows in Nebraska. Nelson and Smoot [39] reported no difference in corn yield in single and twin rows when planted on $76 \mathrm{~cm}$ centers. Yield of twin-row peanut (Arachis hypogaea L.) is often higher than yield of single-row peanut [40-43]. Response of cotton to twin-row plantings has been inconsistent $[44,45]$. Although results for these crops are mixed relative to improvement in yield due to twin-row planting compared with singerow planting, yield of corn, cotton, peanut, and soybean is generally not reduced when planted in twin-row planting patterns.

Drought is a major concern in many regions of the US with respect to corn production, especially on those in the coastal plain regions with sandy soils [46]. Stetzel et al. [47] reported that poor ear development has a profound impact on corn yields but may be attributed to factors other than drought stress. Arrested ears are shorter than normal ears and have a much lower kernel count; however, plants do not show signs of poor ear development until silk emergence and grain fill. Husks are more slender in appearance, and silk numbers are lower compared to plants which exhibit normal ear development. Stetzel et al. [47] also suggested that arrested ear development may result from the application of a nonionic surfactant prior to full tassel of corn [48]. Arrested ear development is generally not uniform across fields, as normal ears can be found towards the outer edges of the field [47] suggesting that stress from crowding of plants may contribute to arrested ear syndrome. Corn growing at relatively high densities can result in reduced pollination caused by asynchrony between delayed silk emergence compared with tassel emergence $[26,49]$. Although the number of days to tasseling was not affected across populations ranging from 60,000 to 135,000 plants $\mathrm{ha}^{-1}$, tasseling period was affected differently by twin- and single-row planting patterns $[26,39,49]$. Impact of twin-row planting at higher than recommended seeding rates has not been evaluated in North Carolina with respect to ear development and grain yield of corn.

Developing weed management strategies in corn that use more than one herbicide mode of action is important in managing herbicide-resistant biotypes. Coupling effective and diverse herbicide modes of actions with cultural practices such as twin-row panting patterns could lead to more effective weed management in corn. Interactions of these variables have not been evaluated with corn grown in the coastal plain of North Carolina with glyphosate-resistant and glufosinate-resistant hybrids. Therefore, research was conducted to compare weed control and corn development and yield when diverse herbicide programs were used in single- and twin-row planting patterns.

\section{Materials and Methods}

2.1. Locations, Soils, Tillage, and Irrigation. Field experiments were conducted in North Carolina during 2011 in one field and during 2012 in two separate fields at the Peanut Belt Research Station located near Lewiston-Woodville (36.07N, $-77.11 \mathrm{~W})$. The experiment was also conducted during 2012 in two separate fields at the Upper Coastal Plain Research Station located near Rocky Mount (35.84N, -77.67W) and in one field at the Tidewater Research Station located near Plymouth $(35.86 \mathrm{~N},-76.74 \mathrm{~W})$. Soils at Rocky Mount, LewistonWoodville, and Plymouth were a Norfolk loamy sand (fineloamy, kaolinitic, thermic Typic Kandiudults), a Goldsboro sandy loam (fine-loamy, siliceous, subactive, thermic Aquic Paleudults), and an Autryville loamy sand (loamy, siliceous, subactive, thermic Aquic Paleudults), respectively. Experiments were planted in fields with natural and relatively high populations of common ragweed and Texas panicum at Lewiston-Woodville. Weed population was too low and nonuniform in distribution at Rocky Mount and Plymouth to assess weed control.

Corn was planted after disking, field cultivation, and bedding/subsoiling in rows spaced $91 \mathrm{~cm}$ apart to establish a population of 141,000 plants $^{-1}$ during both years at Rocky Mount and Lewiston-Woodville. At Plymouth in 2012, corn density was 91,000 plants ha ${ }^{-1}$. Corn was planted in single 
rows on $91 \mathrm{~cm}$ centers or in twin rows spaced $20 \mathrm{~cm}$ apart on $91 \mathrm{~cm}$ centers with in-row seeding rate adjusted to establish the same plant population for both planting patterns. Plot size was 2 rows by $9 \mathrm{~m}$ in length. Corn was planted on April 15, 2011 and April 16, 2012 at Rocky Mount and LewistonWoodville, respectively, and April 16, 2012 at Plymouth. Corn at Lewiston-Woodville and Rocky Mount was irrigated with overhead sprinklers delivering $20 \mathrm{~mm}$ each week. Corn was not irrigated at Plymouth.

2.2. Herbicide Treatments. During 2011 only, treatments consisted of 2 levels of corn hybrid expressing either glufosinateor glyphosate-resistance; 2 levels of planting pattern consisting of single or twin rows; and 6 levels of POST herbicide. Herbicide treatments included no herbicide, dicamba, glufosinate or glyphosate (depending on hybrid), atrazine, dicamba plus atrazine, and glufosinate or glyphosate plus atrazine (depending on hybrid). The glufosinate-tolerant hybrid was P1516BVT (DuPont Crop Protection, Wilmington, DE). The glyphosate-tolerant hybrid was P1516HR (DuPont Crop Protection, Wilmington, DE). In 2012, a corn hybrid 1615HR (DuPont Crop Protection, Wilmington, DE) expressing tolerance to both glufosinate and glyphosate was planted. S-metolachlor (Dual II Magnum herbicide, Syngenta Crop Protection, Greensboro, NC) was applied PRE to all plots at all locations at $1700 \mathrm{~g}$ ai ha ${ }^{-1}$. Dicamba (Clarity herbicide, BASF Crop Protection, Research Triangle Park, NC), glufosinate-ammonium (Liberty herbicide, Bayer CropScience, Research Triangle Park, NC), potassium salt of glyphosate (Roundup PowerMAX herbicide, Monsanto Company, St. Louis, MO), and atrazine (Atrazine 4L herbicide, Helena Chemical Company, Collierville, TN) were applied at $140 \mathrm{gaeha}^{-1}, 560 \mathrm{~g} \mathrm{ae} \mathrm{ha}^{-1}, 840 \mathrm{~g} \mathrm{ae} \mathrm{ha}^{-1}$, and $1100 \mathrm{~g}$ ai ha $^{-1}$, respectively. Crop oil concentrate (Crop Oil Concentrate, Helena Chemical Company, Collierville, $\mathrm{TN})$ was included with all treatments containing atrazine. Adjuvant was not included with dicamba, glufosinate, and glyphosate when these herbicides were applied alone.

Herbicides were applied with a $\mathrm{CO}_{2}$-pressurized backpack sprayer calibrated to deliver $145 \mathrm{~L} \mathrm{ha}^{-1}$ using 8002 regular flat-fan nozzles (Teejet Corporation, Wheaton, IL) at $275 \mathrm{kPa}$. All POST treatments were applied on the same day when corn was $25-36 \mathrm{~cm}$ in height and weeds were less than $10 \mathrm{~cm}$ in height.

2.3. Weed Density. Density of common ragweed was recorded 6 weeks after treatment (WAT) at Lewiston-Woodville during 2011 in a $1 \mathrm{~m}^{2}$ section of each plot. Density of both common ragweed and Texas panicum was recorded at this location during 2012. Texas panicum population was inconsistent during 2011 across the experimental area at LewistonWoodville and at Rocky Mount and Plymouth for all weeds present.

2.4. Corn Measurements. The number of days from planting to silk emergence was determined for corn during both years at all locations. Emergence of silks from all plants was recorded in a $3 \mathrm{~m}$ section of each row for all plots. Once a corn plant reached silk emergence, the stalk was marked with a felt marker directly above the ear to prevent counting a plant more than once until pollination ended.

Corn ears were removed by hand, shelled, and dried to $140 \mathrm{~g} \mathrm{~kg}^{-1}$ moisture. Prior to shelling, ear type categories of incomplete, complete, blunt, or nubbin were determined using illustrations [50]. Once each ear was classified, all related ears were bulked into ear type and grain yield was determined for each plot.

The experimental design during 2011 was a split-plot with hybrid serving as whole plot units and combinations of planting patterns and herbicide treatments serving as subplot units. In 2012, the experimental design was a randomized complete block because the hybrid used was tolerant to both glufosinate and glyphosate. Treatments were replicated four times.

2.5. Statistical Analyses. Data for common ragweed and Texas panicum population, silking and ear type, and grain yield were subjected to analysis of variance for a two (hybrid) by two (planting pattern) by six (POST herbicide treatment) factorial arrangement of treatments during 2011, using the PROC GLM procedure in SAS (SAS v9.2, SAS Institute Inc., Cary, NC). In 2012, data were subjected to analysis of variance for a two (planting pattern) by six (POST herbicide treatment) factorial arrangement of treatments. Means of significant main effects and interactions were separated using Fisher's protected LSD test at $P \leq 0.05$. Pearson correlation coefficients were determined for all parameters at $P \leq 0.05$ (SAS v9.2, SAS Institute, Cary, NC).

At Rocky Mount and Plymouth, weed populations were very low and nonuniform; therefore herbicide program was not considered in the statistical analysis. Data from these locations and for the most effective herbicide treatment in controlling common ragweed and Texas panicum at Lewiston-Woodville during both years were combined to determine the effect of twin-row and single-row planting patterns on corn yield under weed-free conditions. Silk emergence, ear type, and yield data were subjected to ANOVA using the PROC GLM procedure in SAS for a 7 (trial) by 2 (planting pattern) factorial arrangement of treatments. Significant main effects and interactions were separated using Fisher's protected LSD test at $P \leq 0.05$.

\section{Results and Discussion}

3.1. Weed Density. During 2011, with the exception of the main effect of POST herbicide program $(P \leq 0.0001)$, no other main effects or interactions $(P \geq 0.1937)$ were observed for common ragweed density. Application of a POST herbicide decreased density of common ragweed regardless of POST herbicide treatment compared with $S$ metolachlor alone (Table 1). Lack of an interaction of hybrid and herbicide program suggests that both glufosinate and glyphosate are equally effective in controlling common ragweed when applied using the appropriate herbicide-tolerant hybrid [17]. 
TABLE 1: Influence of herbicide program on common ragweed density 6 weeks after treatment (WAT), corn grain yield, and days from planting to silking during $2011^{\mathrm{a}}$.

\begin{tabular}{|c|c|c|c|c|}
\hline \multirow{3}{*}{ Herbicides applied postemergence ${ }^{b}$} & \multirow{3}{*}{$\begin{array}{l}\text { Herbicide rate } \\
\mathrm{g} \mathrm{ha}^{-1}\end{array}$} & \multirow{3}{*}{$\begin{array}{c}\text { Common ragweed } \\
\text { Density } 6 \text { WAT } \\
\text { Number } \mathrm{m}^{-2}\end{array}$} & \multicolumn{2}{|c|}{ Corn } \\
\hline & & & Grain yield & Time to silking \\
\hline & & & $\mathrm{kg} \mathrm{ha}^{-1}$ & $\mathrm{~d}$ \\
\hline No POST herbicide & - & $19^{\mathrm{a}}$ & $3290^{\mathrm{b}}$ & $70^{\mathrm{a}}$ \\
\hline Dicamba & 140 & $0^{\mathrm{b}}$ & $4140^{\mathrm{a}}$ & $68^{\mathrm{c}}$ \\
\hline Glyphosate or glufosinate & 560 or 840 & $1^{\mathrm{b}}$ & $4140^{\mathrm{a}}$ & $68^{c}$ \\
\hline Atrazine & 1100 & $2^{\mathrm{b}}$ & $3910^{\mathrm{ab}}$ & $69^{\mathrm{b}}$ \\
\hline Atrazine plus dicamba & $1100+140$ & $0^{\mathrm{b}}$ & $4180^{\mathrm{a}}$ & $69^{\mathrm{b}}$ \\
\hline Atrazine plus dicamba plus glyphosate or glufosinate & $1100+560$ or 840 & $0^{\mathrm{b}}$ & $4710^{\mathrm{a}}$ & $69^{\mathrm{b}}$ \\
\hline
\end{tabular}

${ }^{a}$ Means within a column followed by the same letter are not significantly different at $P \leq 0.05$. Data are pooled over hybrid and planting patterns.

${ }^{\mathrm{b}}$ Glufosinate and glyphosate applied to the appropriate herbicide-tolerant hybrid. S-metolachlor was applied PRE over the entire test area immediately after planting.

TABLE 2: Common ragweed and Texas panicum densities 6 weeks after treatment as influenced by herbicide program during 2012 at LewistonWoodville.

\begin{tabular}{|c|c|c|c|c|}
\hline \multirow{3}{*}{ Herbicides applied postemergence ${ }^{\mathrm{ab}}$} & \multirow{3}{*}{$\begin{array}{l}\text { Herbicide rate } \\
\qquad \mathrm{gha}^{-1}\end{array}$} & \multirow{3}{*}{ Common ragweed $^{\mathrm{c}}$} & \multicolumn{2}{|c|}{ Texas panicum $^{\mathrm{d}}$} \\
\hline & & & \multirow{2}{*}{\multicolumn{2}{|c|}{$\begin{array}{l}\text { Field } 1 \\
\text { Number in } \mathrm{m}^{2}\end{array}$}} \\
\hline & & & & \\
\hline No POST herbicide & - & $20.1^{\mathrm{a}}$ & $10.5^{\mathrm{b}}$ & $22.1^{\mathrm{bc}}$ \\
\hline Dicamba & 140 & $0^{\mathrm{b}}$ & $21^{\mathrm{a}}$ & $42.5^{\mathrm{a}}$ \\
\hline Glufosinate & 560 & $1.1^{\mathrm{b}}$ & $17.3^{\mathrm{ab}}$ & $27.5^{\mathrm{b}}$ \\
\hline Glyphosate & 840 & $3.3^{\mathrm{b}}$ & $12.8^{\mathrm{ab}}$ & $17.2^{\mathrm{c}}$ \\
\hline Atrazine & 1100 & $0.3^{\mathrm{b}}$ & $18^{\mathrm{ab}}$ & $41.7^{\mathrm{a}}$ \\
\hline Atrazine plus dicamba & $1100+140$ & $0.1^{\mathrm{b}}$ & $13.3^{\mathrm{ab}}$ & $44.1^{\mathrm{a}}$ \\
\hline Atrazine plus glufosinate & $1100+560$ & $1.1^{\mathrm{b}}$ & $15.4^{\mathrm{ab}}$ & $19.1^{\mathrm{bc}}$ \\
\hline Atrazine plus glyphosate & $1100+840$ & $0.5^{\mathrm{b}}$ & $13.8^{\mathrm{ab}}$ & $23.5^{\mathrm{bc}}$ \\
\hline
\end{tabular}

a-metolachlor applied PRE to all plots immediately after planting.

${ }^{\mathrm{b}}$ The corn hybrid was tolerant of both glufosinate and glyphosate.

${ }^{c}$ Means followed by the same letter are not significantly different at $P \leq 0.05$. Data are pooled over fields and planting patterns.

${ }^{\mathrm{d}}$ Means followed by the same letter are not significantly different at $P \leq 0.05$. Data are pooled over planting patterns.

During 2012, the interaction of trial by planting pattern by herbicide program was not significant for common ragweed density $(P=0.7028)$ or Texas panicum density $(P=$ $0.2004)$. The main effect of herbicide was significant for both common ragweed and Texas panicum density $(P \leq 0.0001)$. The interaction of trial by herbicide was not significant for common ragweed density $(P=0.6448)$ but was significant for Texas panicum density $(P \leq 0.0001)$. Density of both weed species was not influenced by the main effect of planting pattern $(P \geq 0.6728)$ or the interaction of trial by planting pattern $(P \geq 0.4368)$. The interaction of planting pattern and POST herbicide program was not significant for common ragweed density $(P=0.7909)$ or Texas panicum density $(P=0.2898)$.

When pooled over fields during 2012, common ragweed density decreased from 20.1 plants $\mathrm{m}^{-2}$ to 3.3 plants $\mathrm{m}^{-2}$ or less 6 WAT (Table 2) corresponding to a reduction in weed density of at least $84 \%$. Other research [17-20] has demonstrated that atrazine, dicamba, glufosinate, and glyphosate control common ragweed. Differences in Texas panicum density between fields were associated with fewer differences observed between treatments in field 1 compared with more differences among treatments in field 2 (Table 2). A higher density in the $S$-metolachlor control was noted in field 2 compared with field 1 (22.1 versus 10.5 plant $\mathrm{m}^{-2}$ ) and may have contributed to the ability of treatment means to separate statistically. In field 1, density of Texas panicum was higher when dicamba was applied compared with $S$-metolachlor alone (Table 2). There was no difference in density when comparing all other POST herbicide treatments with $S$ metolachlor in this field. In contrast, in field 2 density of Texas panicum was similar to the $S$-metolachlor control for all treatments except atrazine or dicamba alone or when these herbicides were co-applied (Table 2). Higher density of Texas panicum following dicamba or atrazine could be explained partially by ineffectiveness of these herbicides in controlling Texas panicum [17]. However, differences in density of weeds may have been associated with weeds emerging after herbicides had their full impact and may not have been related directly to herbicide efficacy. This can be explained by comparing common ragweed density to Texas panicum density. The higher control of common ragweed by herbicides most likely led to a higher density of Texas panicum because there was very little interference of Texas panicum growth 
TABLE 3: Days from planting to initial silk emergence and silking duration as influenced by herbicide program during 2012 at LewistonWoodville.

\begin{tabular}{|c|c|c|c|c|c|c|}
\hline \multirow{4}{*}{$\begin{array}{l}\text { Herbicides applied } \\
\text { postemergence }^{\mathrm{a}}\end{array}$} & \multicolumn{6}{|c|}{ Silking ${ }^{\mathrm{b}}$} \\
\hline & \multirow{3}{*}{$\begin{array}{l}\text { Herbicide rate } \\
\qquad \mathrm{gha}^{-1}\end{array}$} & \multicolumn{2}{|c|}{ Time from planting to initial silking } & \multicolumn{2}{|c|}{ Time from silk initiation to final silking } & \multirow{3}{*}{$\begin{array}{c}\text { Grain yield } \\
\mathrm{kg} \mathrm{ha}^{-1}\end{array}$} \\
\hline & & Field 1 & Field 2 & Field 1 & Field 2 & \\
\hline & & & & $\mathrm{d}$ & & \\
\hline No POST herbicide & - & $66^{\mathrm{a}}$ & $68^{\mathrm{a}}$ & $12^{\mathrm{a}}$ & $11^{\mathrm{d}}$ & $3570^{c}$ \\
\hline Dicamba & 140 & $66^{\mathrm{a}}$ & $64^{\mathrm{bc}}$ & $11^{\mathrm{a}}$ & $15^{\mathrm{ab}}$ & $4050^{\mathrm{bc}}$ \\
\hline Glufosinate & 560 & $66^{\mathrm{a}}$ & $63^{c}$ & $11^{\mathrm{a}}$ & $15^{\mathrm{ab}}$ & $4950^{\mathrm{a}}$ \\
\hline Glyphosate & 840 & $66^{\mathrm{a}}$ & $63^{c}$ & $11^{\mathrm{a}}$ & $15^{\mathrm{ab}}$ & $4530^{\mathrm{ab}}$ \\
\hline Atrazine & 1100 & $66^{\mathrm{a}}$ & $65^{\mathrm{b}}$ & $11^{\mathrm{a}}$ & $14^{\mathrm{bc}}$ & $3620^{\mathrm{c}}$ \\
\hline Atrazine plus dicamba & $1100+140$ & $66^{\mathrm{a}}$ & $65^{\mathrm{b}}$ & $11^{\mathrm{a}}$ & $13^{\mathrm{c}}$ & $4220^{\mathrm{b}}$ \\
\hline Atrazine plus glufosinate & $1100+560$ & $66^{\mathrm{a}}$ & $63^{c}$ & $12^{\mathrm{a}}$ & $16^{\mathrm{a}}$ & $3660^{\mathrm{c}}$ \\
\hline Atrazine plus glyphosate & $1100+840$ & $66^{\mathrm{a}}$ & $64^{\mathrm{bc}}$ & $12^{\mathrm{a}}$ & $15^{\mathrm{ab}}$ & $4290^{\mathrm{b}}$ \\
\hline
\end{tabular}

${ }^{\mathrm{a}} \mathrm{S}$-metolachlor applied PRE to all plots immediately after planting.

${ }^{\mathrm{b}}$ Means within a field followed by the same letter are not significantly different at $P \leq 0.05$. Data are pooled over planting patterns.

${ }^{c}$ Means followed by the same letter are not significantly different at $P \leq 0.05$. Data are pooled over planting patterns.

by common ragweed. These data also suggest that in fields with common ragweed and Texas panicum, additional POST herbicides most likely will be required to obtain season-long weed control in corn.

3.2. Corn Response. The interaction of hybrid, herbicide program, and planting pattern was not significant for any of the measurements associated with corn growth during $2011(P=0.1836)$. Corn stand and height were affected by main effect of hybrid and both main effects of hybrid and POST herbicides, respectively $(P \leq 0.0223)$. Grain yield was affected only by herbicide program $(P=0.0368)$ but not by hybrid $(P=0.6721)$, planting pattern $(P=0.6861)$, or the interaction of these treatment factors $(P=0.0589)$. With the exception of time to silking, herbicide treatments did not affect ear type or duration of silking $(P \geq 0.1960)$. These data suggest that twin row planting patterns offer no advantage over single rows when common ragweed is the only weed present. Corn grain yield was higher when POST herbicides were applied compared with $S$-metolachlor except when atrazine was applied alone (Table 1). Fewer days to silking were noted when POST herbicides were applied, with dicamba, glufosinate, and glyphosate having the fewest days to first silking (Table 1).

During 2012, the interaction of trial by herbicide program was noted for days to first silking $(P \leq 0.0001)$ and duration of silking $(P \leq 0.0001)$. Corn grain yield was affected by the main effect of herbicide program $(P \leq 0.0001)$ and the interaction of trial by planting pattern $(P=0.0476)$. Herbicide program, planting pattern, and the interaction of planting pattern and herbicide program did not affect ear type $(P \geq 0.1062)$.

The interaction of trial by herbicide program occurred because there was no difference in silk emergence among POST herbicide programs in field 1 compared with differences up to 5 days in silk emergence among treatments in field 2 (Table 3). Time to silking decreased when POST herbicides were applied when compared with $S$-metolachlor alone
TABLE 4: Influence of planting pattern on corn grain yield during 2012 at Lewiston-Woodville.

\begin{tabular}{|c|c|c|}
\hline \multirow[b]{2}{*}{ Planting pattern ${ }^{\mathrm{a}}$} & \multicolumn{2}{|c|}{ Corn grain yield ${ }^{\mathrm{b}}$} \\
\hline & Field 1 & Field 2 \\
\hline Single row & $4830^{b}$ & $3150^{\mathrm{a}}$ \\
\hline Twin row & $5400^{\mathrm{a}}$ & $3120^{\mathrm{a}}$ \\
\hline \multicolumn{3}{|c|}{$\begin{array}{l}\text { a Single rows consisted of planting corn on } 91 \mathrm{~cm} \text { centers. Twin rows consisted } \\
\text { of planting corn in rows spaced } 20 \mathrm{~cm} \text { apart on } 91 \mathrm{~cm} \text { centers. In-row } \\
\text { seeding rate adjusted to establish the same plant population for both planting } \\
\text { patterns. }\end{array}$} \\
\hline \multicolumn{3}{|c|}{$\begin{array}{l}{ }^{\mathrm{b}} \text { Means within a field followed by the same letter are not significantly } \\
\text { different at } P \leq 0.05 \text {. Data are pooled over herbicide programs. }\end{array}$} \\
\hline
\end{tabular}

(Table 3). Similarly, applying POST herbicides increased the duration of silking compared with $S$-metolachlor alone (Table 3). The difference in silk emergence between fields 1 and 2 could not be explained.

When pooled over fields during 2012, corn grain yield was similar when dicamba and atrazine were applied alone and when atrazine was applied with glufosinate, and yield following these herbicide treatments did not exceed that of $S$-metolachlor alone (Table 3). The highest yields were noted when glufosinate and glyphosate were applied alone. Grain yield was higher in one of two fields when corn was planted in twin rows compared with single rows (Table 4). Although inconsistent, yield of corn can be higher when planted in twin rows compared to planting in single rows $[33,38,39]$.

3.3. Correlations of Weed and Corn Response. When pooled over trials where both weed species were present, correlations of common ragweed density and Texas panicum density with corn stand and height were not significant (Table 5). However, density of these weeds was negatively correlated with grain yield. In contrast, common ragweed density was positively correlated with days to first silk while Texas panicum density was negatively correlated with days to first 
TABle 5: Pearson correlations of common ragweed and Texas panicum density with corn growth and yield response at Lewiston-Woodville.

\begin{tabular}{lcccc}
\hline Source & \multicolumn{2}{c}{ Common ragweed } & \multicolumn{2}{c}{ Texas panicum } \\
\hline Stand & $P>F$ & $R^{2}$ & $P>F$ & 0.1628 \\
Height & 0.0730 & -0.16 & 0.4520 & 0.12 \\
Yield & 0.0757 & -0.16 & $<0.0001$ & 0.07 \\
Days to first silk & 0.0141 & -0.23 & 0.0147 & -0.43 \\
Silk duration & 0.0008 & 0.30 & 0.0046 & -0.22 \\
\hline
\end{tabular}

silk. Silk duration was correlated with Texas panicum density but not common ragweed density. A higher density of both common ragweed and Texas panicum would be expected to decrease grain yield and explain the negative correlation. The significant but differential response of days to first silking is more difficult to explain when comparing the weed species. A delay in reaching silking due to interference by common ragweed is reasonable in that weeds can delay early season growth and development which may adversely affect grain yield. A negative correlation between common ragweed and Texas panicum density and days to first silking implies that at higher Texas panicum densities the number of days to silking would be less than the number of days required with fewer weeds. These differences may be due in part to when weeds emerged in corn and how POST herbicides impacted densities later in the season. Common ragweed density and Texas panicum density were negatively correlated $(P=0.1178$, $R=-0.14$, data not shown in tables). In these fields, common ragweed emerged before Texas panicum and would have resulted in less Texas panicum present when herbicides were not applied to control common ragweed. When common ragweed was controlled by herbicides, more Texas panicum would have been present because of little interference from common ragweed. Silk duration was not affected by common ragweed but was affected by Texas panicum (Table 5). The positive relationship of weed population with days to silking most likely resulted from greater interference with corn and accompanying stress that delayed crop development. Blunt weight $(P \leq 0.0001, R=0.47)$ and complete weight $(P \leq$ $0.0001, R=0.45$ ) were positively correlated with corn grain yield while duration of silking and grain yield were negatively correlated $(P \leq 0.0001, R=-0.44)$ (data not shown in tables).

3.4. Corn Response to Planting Pattern in Absence of Weeds. When pooled over fields, locations (Lewiston-Woodville, Plymouth, and Rocky Mount), years (2011 and 2012), days to silking, silk duration, and corn stand were not affected by planting pattern or the interaction of trial by planting pattern ( $P=0.1669$ to 0.5299 ) (data not shown in tables). In contrast, two distinct groups of trials emerged when considering the impact of plant population on corn grain yield. For 5 of the trials, corn grain yield increased from $5830 \mathrm{~kg} \mathrm{ha}^{-1}$ in single rows to $7180 \mathrm{~kg} \mathrm{ha}^{-1}$ in twin rows $(P=0.0007$, data not shown in tables). In the remaining two trials grain yield was not affected by planting pattern $(P=0.2442)$ with yield ranging from 3870 to $4380 \mathrm{~kg} \mathrm{ha}^{-1}$ (data not shown in tables). The higher yield of corn in twin rows occurred in trials where higher yield potential was observed (7180 $\mathrm{kg} \mathrm{ha}^{-1}$ versus $4380 \mathrm{~kg} \mathrm{ha}^{-1}$ for maximum yield). These data suggest that a positive response to twin-row planting may be possible when environmental and edaphic conditions favor higher yields compared with conditions that are less favorable. The positive response to twin rows also may have been a function of higher than recommended plant populations in single rows that lowered yield potential in this planting pattern. Competition of plants for water and other essential components that contribute to yield may have been more limited in this planting pattern compared with the twin rows because of plant arrangement. Less competition would have occurred between individual plants in twin rows compared with single rows when total plant population was similar for both planting patterns. While the experimental procedure did not allow comparison of twin rows at higher plant populations with more modest populations generally recommended for single-row planting patterns for corn, results do suggest that twin rows are a planting pattern with potential to increase yield by minimizing interplant competition often observed at higher plant populations.

\section{Conclusion}

While broad conclusions from this experiment are limited due to the number of years, experimental procedures, and locations, some reasonable observations can be made. Postemergence herbicides reduced weed populations compared with populations for $S$-metolachlor alone during both years regardless of corn hybrid. Weed density was not affected by planting pattern; however, in absence of weeds, yield was higher in 5 of 7 trials when corn was planted in twin rows rather than single rows, suggesting that twin-row planting patterns may be an effective alternative to single-row planting patterns in high-yielding environments when total plant populations are similar and corn is seeded at relatively high rates. Only three genotypes were used in the present experiment. Additional research with a broader group of corn hybrids is needed to determine the value of twin-row patterns on wide-scale adoption in corn. However, the value of twinrow planting in corn has not been clearly determined in North Carolina and surrounding states. Results from these experiments will assist growers and their advisors in making decisions on adoption of twin-row planting patterns in corn.

\section{Conflict of Interests}

None of the authors has a conflict of interests in terms of the products mentioned in the paper. 


\section{Acknowledgments}

The North Carolina Corn Growers Association provided financial support for this research. Appreciation is expressed to staff at the Peanut Belt Research Station, Tidewater Research Station, and Upper Coastal Plain Research Station for technical assistance. Appreciation is addressed to Dewayne Johnson, Leah Boerema, Matthew Barrow, Joseph Oakes, Jamie Hinton, and Chelsea McPherson for technical assistance.

\section{References}

[1] G. W. Bird, K. M. Maredia, D. Dakouo, and D. Mota-Sanchez, "Role of integrated pest management and sustainable development," in Integrated Pest Management in the Global Arena, pp. 73-85, CABI Publishing, Wallingford, UK, 2003.

[2] T. M. Webster, "Weed survey-southern states," Proceedings Southern Weed Science Society, vol. 53, pp. 247-252, 2000.

[3] E. P. Prostko, T. L. Grey, and J. W. Davis, “Texas panicum (Panicum texanum) control in irrigated field corn (Zea mays) with foramsulfuron, glyphosate, nicosulfuron, and pendimethalin," Weed Technology, vol. 20, no. 4, pp. 961-964, 2006.

[4] W. C. Johnson III and B. G. Mullinix, "Efficacy and economic analysis of Texas panicum (Panicum texanum) management systems in corn (Zea mays)," Weed Technology, vol. 4, no. 4, pp. 754-758, 1990.

[5] W. E. Thomas, I. C. Burke, and J. W. Wilcut, "Weed management in glyphosate-resistant corn with glyphosate, halosulfuron, and mesotrione," Weed Technology, vol. 18, no. 3, pp. 826-834, 2004.

[6] M. R. Obermeier and G. Kapusta, "Postemergence broadleaf weed control in corn (Zea mays) with CGA-152005," Weed Technology, vol. 10, no. 4, pp. 689-698, 1996.

[7] H. M. LeBaron, J. E. McFarland, and O. C. Burnside, The Trizaine Herbicides: A Milestone in the Development of Weed Control Technology, The Triazine Herbicides, 50 Years Revolutionizing Agriculture, 2008.

[8] F. Ackerman, “The economics of atrazine," International Journal of Occupational and Environmental Health, vol. 13, no. 4, pp. 441-449, 2007.

[9] T. B. Hayes, K. Haston, M. Tsui, A. Hoang, C. Haeffele, and A. Vonk, "Atrazine-induced hermaphroditism at $0.1 \mathrm{ppb}$ in American leopard frogs (Rana pipiens): laboratory and field evidence," Environmental Health Perspectives, vol. 111, no. 4, pp. 568-575, 2003.

[10] B. T. Croll, "Pesticides in surface waters and groundwaters," Journal of the Institution of Water and Environmental Management, vol. 5, no. 4, pp. 389-395, 1991.

[11] J. S. Holt and H. M. LeBaron, "Significance and distribution of herbicide resistance," Weed Technology, vol. 4, no. 1, pp. 141-149, 1990.

[12] J. Gressel and L. A. Segel, "Modelling the effectiveness of herbicide rotations and mixtures as strategies to delay or preclude resistance," Weed Technology, vol. 4, pp. 186-198, 1990.

[13] G. R. Stephenson, M. D. Dykstra, R. D. McLaren, and A. S. Hamill, "Agronomic practices influencing triazine-resitant weed distribution in Ontario," Weed Technology, vol. 4, pp. 199207, 1990.

[14] V. K. Nandula, K. N. Reddy, S. O. Duke, and D. H. Poston, "Glyphosate-resistant weeds: current status and future outlook," Outlooks on Pest Management, vol. 16, no. 4, pp. 183-187, 2005.
[15] I. Heap, "The International Survey of Herbicide Resistant Weeds," 2013, http://www.weedscience.org.

[16] N. Soltani, C. Shropshire, and P. H. Sikkema, "Giant ragweed (Ambrosia trifida L.) control in corn," Canadian Journal of Plant Science, vol. 91, no. 3, pp. 577-581, 2011.

[17] W. Everman, "Weed control in corn," in North Carolina Agricultural Chemicals Manual, vol. AG-1, pp. 224-230, 2014.

[18] S. D. Askew and J. W. Wilcut, "Cost and weed management with herbicide programs in glyphosate-resistant cotton (Gossypium hirsutum)," Weed Technology, vol. 13, no. 2, pp. 308-313, 1999.

[19] J. L. Corbett, S. D. Askew, W. E. Thomas, and J. W. Wilcut, "Weed efficacy evaluations for bromoxynil, glufosinate, glyphosate, pyrithiobac, and sulfosate," Weed Technology, vol. 18, no. 2, pp. 443-453, 2004.

[20] A. S. Culpepper, A. C. York, R. B. Batts, and K. M. Jennings, "Weed management in glufosinate- and glyphosate-resistant soybean (Glycine max)," Weed Technology, vol. 14, no. 1, pp. 7788,2000 .

[21] W. G. Duncan, “The relationship between corn population and yield," Agronomy Journal, vol. 50, pp. 82-84, 1958.

[22] W. G. Duncan, "A theory to explain the relationship between corn population and grain yield," Crop Science, vol. 24, pp. 1141$1145,1984$.

[23] P. H. Sikkema, R. E. Nurse, T. Welacky, and A. S. Hamill, "Reduced herbicide rates provide acceptable weed control regardless of corn planting strategy in Ontario field corn," Canadian Journal of Plant Science, vol. 88, no. 2, pp. 373-378, 2008.

[24] J. R. Teasdale, "Influence of narrow row/high population corn (Zea mays) on weed control and light transmittance," Weed Technology, vol. 9, no. 1, pp. 113-118, 1995.

[25] J. R. Teasdale, "Influence of corn (Zea mays) population and row spacing on corn and velvetleaf (Abutilon theophrasti) yield," Weed Science, vol. 46, no. 4, pp. 447-453, 1998.

[26] A. M. Hashemi, S. J. Herbert, and D. H. Putnam, "Yield response of corn to crowding stress," Agronomy Journal, vol. 97, no. 3, pp. 839-846, 2005.

[27] E. E. N. A. Bonaparte and R. I. Brawn, "Effects of plant density and planting date on leaf number and some developmental events in corn," Canadian Journal of Plant Science, vol. 56, pp. 691-698, 1976.

[28] M. J. Ottman and L. F. Welch, "Planting patterns and radiation interception, plant nutrient concentration, and yield in corn," Agronomy Journal, vol. 81, pp. 167-174, 1989.

[29] D. M. Lambert and J. Lowenberg-DeBoer, "Economic analysis of row spacing for corn and soybean," Agronomy Journal, vol. 95, no. 3, pp. 564-573, 2003.

[30] Z. Ghafar and A. K. Watson, "Effect of corn population on the growth of yellow nutsedge," Weed Science, vol. 31, pp. 588-592, 1983.

[31] S. M. McLachlan, M. Tollenaar, C. J. Swanton, and S. F. Weise, "Effect of corn-induced shading on dry matter accumulation, distribution, and architecture of redroot pigweed," Weed Science, vol. 41, no. 4, pp. 568-573, 1993.

[32] G. A. Johnson, T. R. Hoverstad, and R. E. Greenwald, "Integrated weed management using narrow corn row spacing, herbicides, and cultivation," Agronomy Journal, vol. 90, no. 1, pp. 40-46, 1998.

[33] H. A. Bruns, M. W. Ebelhar, and H. K. Abbas, "Comparing single-row and twin-row corn production in the Mid South," Crop Management, vol. 11, no. 1, 2012. 
[34] W. J. Grichar, "Row spacing, plant populations, and cultivar effects on soybean production along the Texas Gulf Coast," Crop Management, vol. 6, no. 1, 2007.

[35] H. A. Bruns, "Comparisons of single-row and twin-row soybean production in the Mid-South," Agronomy Journal, vol. 103, no. 3, pp. 702-708, 2011.

[36] H. A. Bruns, "Planting date, rate, and twin-row vs. single-row soybean in the mid-south," Agronomy Journal, vol. 103, no. 5, pp. 1308-1313, 2011.

[37] H. Gozubenli, M. Kilinc, O. Sener, and O. Konuskan, "Effects of single and twin row planting on yield and yield components in maize," Asian Journal of Plant Sciences, vol. 3, pp. 203-206, 2004.

[38] M. J. Novacek, S. C. Mason, T. D. Galusha, and M. Yaseen, “Twin rows minimally impact irrigated maize yield, morphology, and lodging," Agronomy Journal, vol. 105, no. 1, pp. 268-276, 2013.

[39] K. A. Nelson and R. L. Smoot, "Twin- and single-row corn production in northeast Missouri," Crop Management, 2009.

[40] E. W. Hauser and G. A. Buchanan, "Influence of row spacing, seeding rates, and herbicide systems on the competitiveness and yield of peanuts," Peanut Science, vol. 8, pp. 78-81, 1981.

[41] E. W. Hauser and G. A. Buchanan, "Production of peanuts as affected by weed competition and row spacing," Alabama Agricultural Experiment Station Bulletin, vol. 538, p. 35, 1982.

[42] G. Wehtje, R. H. Walker, M. G. Patterson, and J. A. McGuire, "Influence of twin rows on yield and weed control in peanuts," Peanut Science, vol. 11, pp. 88-91, 1984.

[43] J. E. Lanier, D. L. Jordan, J. F. Spears et al., "Peanut response to planting pattern, row spacing, and irrigation," Agronomy Journal, vol. 96, no. 4, pp. 1066-1072, 2004.

[44] K. N. Reddy, I. C. Burke, J. C. Boykin, and J. Ray Williford, "Narrow-row cotton production under irrigated and nonirrigated environment: plant population and lint yield," Journal of Cotton Science, vol. 13, no. 2, pp. 48-55, 2009.

[45] K. N. Reddy and J. C. Boykin, "Weed control and yield comparisons of twin- and single-row glyphosate-resistant cotton production systems," Weed Technology, vol. 24, no. 2, pp. 95-101, 2010.

[46] E. J. Sadler, P. J. Bauer, and W. J. Busscher, "Site-specific analysis of a droughted corn crop: I. Growth and grain yield," Agronomy Journal, vol. 92, no. 3, pp. 395-402, 2000.

[47] N. Stetzel, K. Wise, B. Nielsen, and C. Gerber, Arrested Ear Development in Hybrid Corn, Purdue Extension Publication, BP-85-W, West Lafayette, Ind, USA, 2011.

[48] L. J. Abendroth, R. W. Elmore, M. J. Boyer, and S. K. Marlay, Corn Growth and Development, Iowa State University Cooperative Extension Publication, Ames, Iowa, USA, 2011.

[49] M. E. Otegui, "Kernel set and flower synchrony within the ear of maize: II. Plant population effects," Crop Science, vol. 37, no. 2, pp. 448-455, 1997.

[50] D. Mueller and R. Pope, Corn Field Guide, Iowa State University Cooperative Extension Service, 2009. 


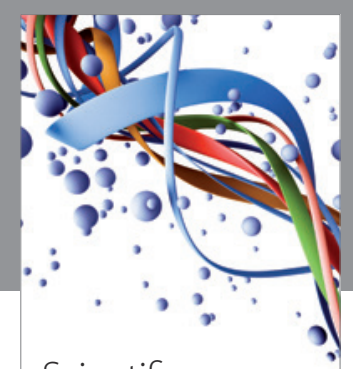

Scientifica
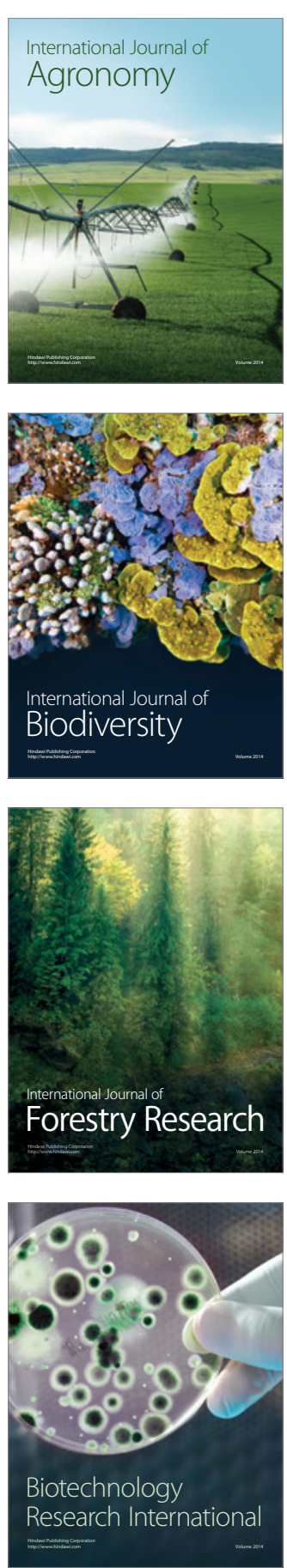
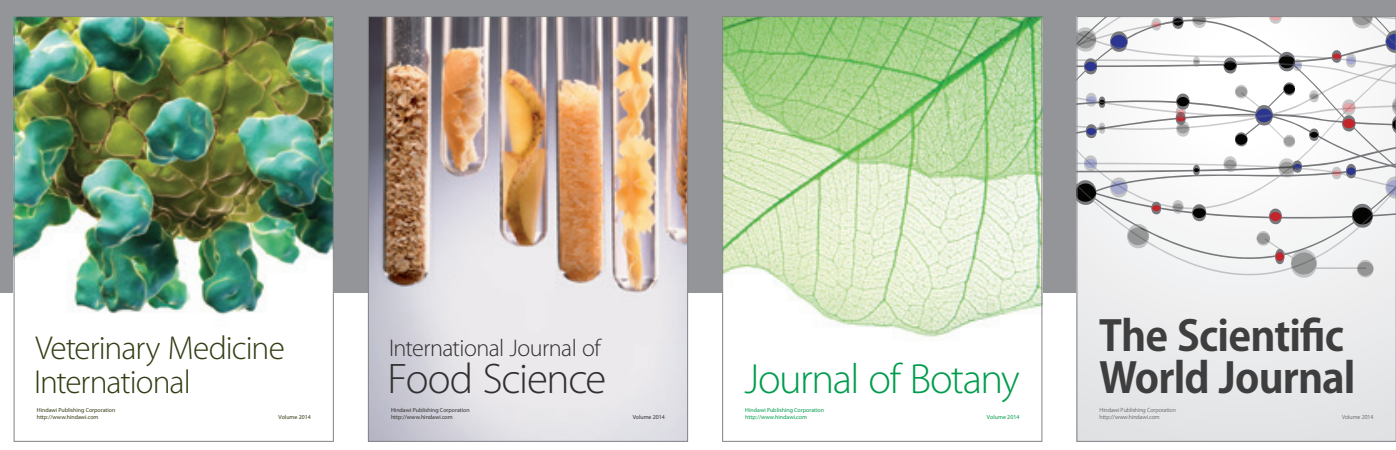

The Scientific World Journal
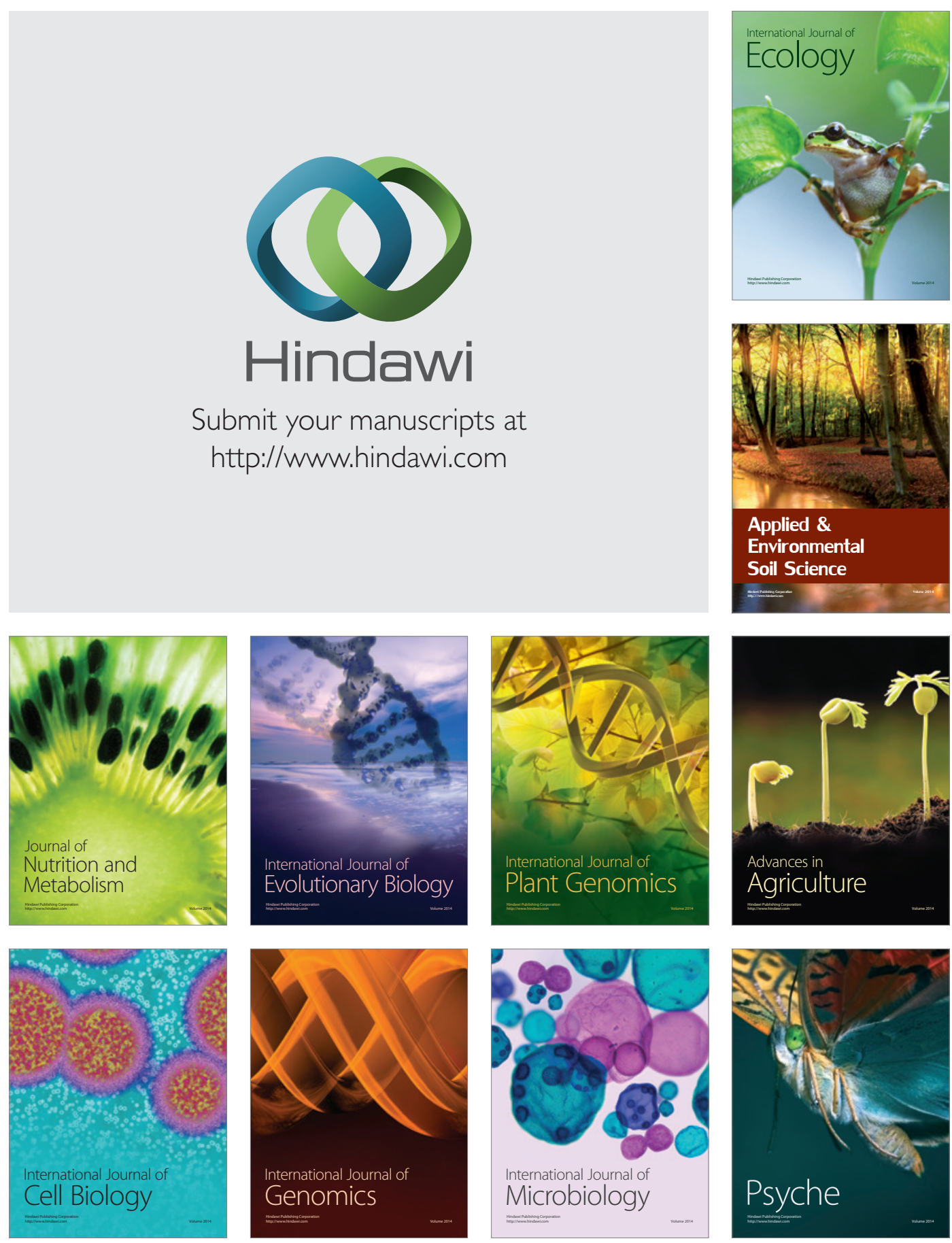